\title{
Peningkatan problem-solving skills dan hasil belajar mahasiswa pada mata kuliah ekologi melalui Blended-PjBL
}

Erna Yayuk ${ }^{1}$, Husamah Husamah ${ }^{2 *}$

${ }^{1}$ Prodi Pendidikan Guru Sekolah Dasar, FKIP, Universitas Muhammadiyah Malang, Jawa

Timur, Indonesia

${ }^{2}$ Prodi Pendidikan Biologi, FKIP, Universitas Muhammadiyah Malang, Jawa Timur, Indonesia

*Coressponding author email: $\underline{\text { usya_bio@umm.ac.id }}$

\section{Artikel info}

Received : 15 August 2019

Revised : 02 October 2019

Accepted : 11 October 2019

Kata kunci:

Blended-PjBL

Ekologi

Hasil belajar

Problem solving skills

\begin{abstract}
ABSTRAK
Implementasi pembelajaran untuk mahasiswa calon guru harus berorientasi pada pembiasaan berani menghadapi masalah dan mampu menyelesaikan masalah tersebut secara cepat dan tepat. Tujuan penelitian ini untuk menganalisis peningkatan problem-solving skills, dan peningkatan hasil belajar mahasiswa Prodi Pendidikan Biologi FKIP UMM pada matakuliah ekologi melalui penerapan Blended-PjBL. Penelitian Tindakan Kelas (PTK) ini dilaksanakan dalam tiga siklus. Siklus tindakan merujuk pada Model Spiral. Sintaks pembelajaran yang diterapkan adalah PjBl, yang dalam kontek Blended-PjBL. PTK ini dilaksanakan di kelas C Angkatan 2017, Mata Kuliah Ekologi, yang berjumlah 35 orang, Semester Genap Tahun Ajaran 2018/2019. Hasil penelitian menunjukkan terjadi peningkatan aspek problem-solving skills sebanyak 23 point, sedangkan hasil belajarnya mengalami peningkatan sebanyak 35 poin. Dengan demikian, dapat ditarik simpulan bahwa penerapan Blended-PjBL mampu meningkatkan problem-solving skills hingga level baik dan hasil belajar hingga level sangat baik pada matakuliah ekologi.
\end{abstract}

\section{ABSTRACT}

Keywords:

Blended-PjBL

Ecology

Learning outcomes

Problem solving skills

Improving problem-solving skills and student learning outcomes in Ecology courses through Blended-PjBL. Implementation of learning for prospective teacher must be oriented to habituation to face problems and be able to solve these problems quickly and accurately. The purpose of this study was to analyze the increasing in problem-solving skills and learning outcomes of Biology Education Study Program FKIP UMM students in ecology courses through the implementation of Blended-PjBL. This Classroom Action Research (CAR) was carried out in three cycles and referred to the Spiral Model. The learning syntax applied was PjBl, which was in the Blended-PjBL context. CAR was held in class 2017-C of Even Semester of Academic Year 2018/2019 with a total of 35 students. The results showed that aspects of problem-solving skills and learning outcome of students increased by 23 points and 35 points, respectively. Thus it can be concluded that the application of Blended-PjBL can improve problemsolving skills to good levels and learning outcomes to outstanding levels in ecology courses.

https://doi.org/10.31331/jipva.v3i2.914

How to Cite: Yayuk, E., \& Husamah, H. (2019). Peningkatan problem-solving skills dan hasil belajar mahasiswa pada mata kuliah Ekologi melalui Blended-PjBL. JIPVA (Jurnal Pendidikan IPA Veteran), 3(2), 100-114. doi: https://doi.org/10.31331/jipva.v3i2.914

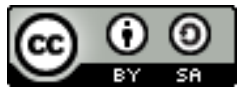

Copyright (C) 2019, Yayuk \& Husamah 


\section{PENDAHULUAN}

Pendidikan tinggi-termasuk dalam hal ini Lembaga Pendidikan Tenaga Kependidikan (LPTK) adalah lembaga yang menghasilkan tenaga pendidik (guru) diberikan tugas untuk mengembangkan potensi mahasiswa (calon guru) untuk membentuk manusia yang dewasa, yang memiliki iman dan ketakwaan, cerdas secara komprehensif, dan memiliki hardskill serta softskill yang seimbang (Caraka \& Ika, 2016; Rohman, 2013; Sukerti, 2016). Potensi ini dapat dicapai melalui berbagai kegiatan, salah satunya adalah melalui kegiatan pembelajaran. Dalam konteks konstruktivisme, pengembangan ini dalam dunia pendidikan menuntut perubahan dalam proses pembelajaran (Ngang, Hashim, \& Yunus, 2015; Pachauri \& Yadav, 2013; Rasmani, Widodo, \& Wibowo, 2017; Rohaeti, 2014; Tang, 2018). Inovasi dan adaptasi dalam pembelajaran harus terus dilakukan. Terlebih bahwa sebagai lembaga penghasil guru, peranan LPTK sangat menentukan dalam meningkatkan kualitas pendidikan dan kehidupan manusia, karena guru merupakan aktor penting yang berperan dalam meningkatkan pendidikan (Filho et al., 2018; Montrieux, Vanderlinde, Schellens, \& De Marez, 2015; Ogunyinka, Okeke, \& Adedoyin, 2015; Serdyukov, 2017).

Sejalan dengan hal tersebut, Program Studi Pendidikan Biologi memiliki tugas utama adalah menyelenggarakan pendidikan berkualitas untuk menghasilkan visi masa depan profesional guru Biologi. Tugasnya sangat berat; karena itu proses pembelajaran yang diterapkan harus tepat (Husamah, 2015). Pembelajaran untuk melengkapi kompetensi calon guru, harus relevan dengan karakteristik, yaitu 1) pembelajaran yang efektif, siswa dituntut aktif mengeksplorasi dan mengolah informasi (Bouwma-Gearhart, Ivanovitch, Aster, \& Bouwma, 2018; Khatoon, Alam, Bukhari, \& Mushtaq, 2014; Mwanda, Odundo, \& Midigo, 2017; Owens \& Tanner, 2017; Tanner, 2017), 2) membantu meningkatkan dan mengembangkan keterampilan berpikir untuk materi yang dipelajari (Bustami, Syafruddin, \& Afriani, 2018; Jeronen, Palmberg, \& Yli-Panula, 2016; Kristianti, Ramli, \& Ariyanto, 2018; Mahanal, Zubaidah, Bahri, \& Dinnurriya, 2016; Nurhamidah, Masykuri, \& Dwiastuti, 2018; Suryawati, Linggasari, \& Arnentis, 2017), dan (3) strategi pembelajaran harus bertujuan untuk membangun kesadaran akan adanya masalah (problem) dan bagaimana menyelesaikannya (problem solving), melatih keterampilan, menumbuhkan sikap ingin tahu, dan membangun motivasi belajar (Allchin, 2013; Darling-Hammond, Flook, Cook-Harvey, Barron, \& Osher, 2019; Ebiere Dorgu, 2016; Fry, Ketteridge, \& Marshall, 2009). Dengan demikian, implementasi pembelajaran di kelas untuk calon guru, sejak awal mereka harus berorientasi pada membangun keingintahuan intelektual layaknya seorang pakar, cerdas, dan berani menghadapi masalah sekaligus mampu menyelesaikan masalah tersebut secara cepat dan tepat.

Program Studi Pendidikan Biologi harus dapat menerapkan proses pembelajaran yang merangsang semua siswa untuk berkembang menjadi lulusan yang memiliki kompetensi penuh (Faisal \& Martin, 2019; Khatoon et al., 2014; Ramlawati, Mun'Im, \& Yunus, 2018; Suryawati et al., 2017) yang memiliki intelektual, profesional, sosial, moral, dan kepribadian (Asyafah, 2014; Hakim, 2015). Salah satu bentuknya adalah mereka memiliki problem solving skills (Shieh \& Chang, 2014; White et al., 2011). Problem-solving skills terdiri atas kemampuan memperoleh informasi, menganalisis situasi, dan mengidentifikasi masalah dengan tujuan menghasilkan alternatif sehingga dapat mengambil suatu tindakan keputusan 
untuk mencapai sasaran (Khoiriyah \& Husamah, 2018; Papathanasiou, Kleisiaris, Fradelos, Kakou, \& Kourkouta, 2014; Syahidatulfalah, 2017).

Salah satu matakuliah yang wajib ditempuh oleh mahasiswa calon guru adalah ekologi yang merupakan gabungan dari ekologi tumbuhan dan ekologi hewan (Husain, Katili, \& Nusantari, 2019; Nursal \& Fauziah, 2013). Hasil observasi menunjukkan bahwa ekologi wajib ditempuh atau dipelajari oleh para calon guru di Prodi Pendidikan Biologi Fakultas Keguruan dan Ilmu Pendidikan Universitas Muhammadiyah Malang (FKIP UMM) dengan kajian materi yang sangat luas. Selama ini, mahasiswa hanya diberikan materi tentang ekologi yang tidak kontekstual dan aplikatif. Hasil wawancara dengan dosen pengampu matakuliah ekologi di Prodi Pendidikan Biologi FKIP UMM menunjukkan bahwa para mahasiswa cenderung tidak mampu mengembangkan aspek problem solving. Rerata problem-solving skill mahasiswa adalah 60, sementara hasil belajar mahasiswa masih $<70$, yaitu hanya mencapai 52 . Hal ini tentu tidak sejalan dengan Mahanal dan Zubaidah (2017) bahwa prinsip pembelajaran biologi harus dilaksanakan untuk mengembangkan kemampuan berpikir, termasuk dalam hal ini aspek problem-solving skills.

Apabila hal tersebut berlanjut, maka sangat memungkinkan menimbulkan dampak negatif bagi mahasiswa karena mereka tidak dapat mencapai tujuan pembelajaran yang telah ditentukan dan lemah dalam kompetensi profesional (Fry et al., 2009; Le, Janssen, \& Wubbels, 2018; Schinske \& Tanner, 2014; Serdyukov, 2017). Oleh karena itu, dosen harus terus menerus mengembangkan kualitas pembelajaran dan target yang ditetapkan yaitu mengembangkan kompetensi dan kemampuan mahasiswa dapat tercapai. Dosen perlu memperbaiki hasil dengan penerapan suatu tindakan yang mampu mengubah hasil belajar ke arah yang lebih baik. Guru perlu mengembangkan atau minimal menerapkan pembelajaran yang berkualitas. Salah satu pembelajaran yang dapat diimplementasikan adalah Blended Project Based Learning (Blended-PjBL).

Beberapa penelitian terkait topik ini adalah Blended-PjBL yang diterapkan pada matakuliah Pengantar Pendidikan efektif untuk mengembangkan aspek thinking skills mahasiswa baru Prodi Pendidikan Biologi, dan Blended-PjBL yang diterapkan di kelas mahasiswa baru Prodi Pendidikan Biologi mampu mengembangkan dan menstimulasi kesadaran metakognitif mahasiswa (Husamah, 2015). Sementara itu, penerapan BlendedPjBL pada pembelajaran kimia berpengaruh terhadap kreativitas tinggi dan rendah serta terhadap hasil belajar aspek pengetahuan dan keterampilan, meskipun tidak ada pengaruh terhadap prestasi belajar aspek sikap (Widyasari, Indriyanti, \& Mulyani, 2018). Blended-PjBL yang diterapkan pada kelas calon guru Pendidikan Sains menunjukkan bahwa aspek critical thinking mereka meningkat (Putri \& Hendawati, 2014), dan implementasi Blended-PjBL yang dirancang dengan tepat, dapat membantu meminimalkan masalah pembelajaran yang umumnya dihadapi pendekatan tradisional atau stand alone traditional lecture-tutorial approach maupun $\mathrm{PjBL}$ atau project-based learning approach (Nepal \& Jenkins, 2011).

Sehubungan dengan itu, problem-solving skills perlu dimiliki calon guru masa depan, begitu pula hasil belajar yang baik dalam bidang biologi (aspek kompetensi profesional dalam hal ini materi ekologi). Oleh karena itu, penelitian tindakan kelas ini perlu untuk dilakukan. Adapun tujuan penelitian ini adalah (1) menganalisis peningkatan problem-solving skills mahasiswa Prodi Pendidikan Biologi FKIP UMM pada matakuliah ekologi melalui penerapan 
Blended-PjBL, dan (2) menganalisis peningkatan hasil belajar mahasiswa pada matakuliah ekologi melalui penerapan Blended-PjBL.

Penelitian ini diharapkan dapat memberikan solusi terhadap upaya peningkatan kualitas pembelajaran mata kuliah ekologi, secara khusus di Prodi Pendidikan Biologi FKIP UMM ataupun diperguruan tinggi lain, bahkan jenjang pendidikan lain yang memiliki karakteristik serupa. Penelitian ini juga akan memperkaya khasanah penelitian dan referensi terkait dengan upaya pengembangan problem-solving skills mahasiswa (peserta didik) dan alternatifalternatif pendekatan pembelajaran-pembelajaran di kelas.

\section{METODE}

\section{Prosedur Penelitian}

Penelitian ini merupakan Penelitian Tindakan Kelas (PTK) dengan pendekatan kualitatif. PTK ini dilaksanakan dalam 3 siklus ( 1 siklus terdiri atas 1 pertemuan 2 dan setiap pertemuan terdiri atas 3 jam pelajaran (3x50 menit). Siklus tindakan merujuk pada Model Spiral yang terdiri atas perencanaan, tindakan, observasi/evaluasi, serta refleksi (Kemmis, McTaggart, \& Nixon, 2014). Sintaks pembelajaran yang diterapkan adalah PjBl (Husamah \& Pantiwati, 2014), yang dalam kontek Blended-PjBL telah dikembangkan oleh Husamah (2015), yaitu (1) memulai dengan pertanyaan esensial atau start with the essential question (dilaksanakan secara tatap muka, pertanyaan terkait dengan tanah dan kehidupan yang ada di dalamnya, serta bagaimana peran hewan/fauna tanah), (2) mendesain rencana proyek atau design a plan for the project (dilaksanakan secara tatap muka, proyek berupa membuat proposal penelitian ekologi hewan tanah), (3) menentukan jadwal atau create a schedule (dilaksanakan secara tatap muka), (4) memantau mahasiswa dan progres proyek yang dikerjakan atau monitor the students and the progress of the project (dilaksanakan secara tatap muka dan daring), (5) menilai hasil capaian/produk atau assess the outcome project (dilaksanakan secara tatap muka dan daring), and 6) mengevaluasi pengalaman mahasiswa atau evaluate the experience (dilaksanakan secara daring).

\section{Waktu dan Tempat Penelitian}

PTK ini dilaksanakan di kelas C Angkatan 2017, Mata Kuliah Ekologi, yang berjumlah 35 orang, Semester Genap Tahun Ajaran 2018/2019, bulan Februari-Juni 2019. Tim peneliti berperan sebagai penyusun instrumen, penyusun perangkat, perancang dan pelaksana tindakan, serta pihak yang melapor hasil kegiatan penelitian. Pelaksanaan dibantu oleh 4 orang observer ( 2 orang dosen dan 2 orang mahasiswa semester akhir).

\section{Data, Instrumen dan Teknik Pengumpulan Data}

Data penelitian ini berupa rekaman pelaksaan sintaks, data problem-solving skills mahasiswa, dan data hasil belajar mahasiswa per siklus, dan nilai akhir mahasiswa. Penilaian problem-solving skills merujuk empat indikator menurut Rhodes (2009), yaitu (1) membangun/merumuskan masalah, (2) menyusun strategi pemecahan masalah, (3) mengusulkan hipotesis pemecahan masalah, dan (4) menjelaskan kelemahan dan kelebihan cara pemecahan masalah. Nilai setiap indikator adalah 0-100, sehingga nilai akhir problemsolving skills merupakan rerata semua indikator. Adapun kriteria mengacu pada merujuk pada Arikunto (2001), seperti pada Tabel 1. 
Data hasil belajar merupakan gabungan dari hasil tes ulangan harian, proses pengerjaan proyek, dan hasil pekerjaan proyek yang dapat diklasifikasi persentase/tingkat hasil belajar mahasiswa, merujuk pada Arikunto (2001) seperti pada Tabel 1. Sementara nilai akhir mahasiswa merujuk pada ketentuan Universitas Muhammadiyah Malang, yang terdiri atas nilai presensi, nilai tugas, nilai praktikum, nilai UTS, dan nilai UAS.

Tabel 1. Kriteria ketercapaian hasil belajar mahasiswa

\begin{tabular}{rc}
\hline Nilai $(\boldsymbol{\%})$ & Kriteria \\
\hline $85-100$ & Sangat baik \\
$70-85$ & Baik \\
$55-70$ & Cukup \\
$40-55$ & Kurang \\
$0-40$ & Sangat kurang \\
\hline
\end{tabular}

\section{HASIL DAN PEMBAHASAN}

\section{Problem-solving skills mahasiswa}

Problem-solving skills merupakan hal yang sangat penting dan tidak dapat diabaikan. (Chaudhry \& Rasool, 2012). Problem-solving skills adalah proses mental dan intelektual untuk mengidentifikasi dan memecahkan masalah dengan tepat agara kesimpulan yang diambilpun akan tepat dan cermat (Syahidatulfalah, 2017). Sehubungan dengan itu, data skor problem-solving skills mahasiswa Prodi Pendidikan Biologi FKIP UMM pada matakuliah ekologi melalui penerapan Blended-PjBL disajikan pada Tabel 2.

Tabel 2. Nilai rerata problem-solving skills mahasiswa pada matakuliah Ekologi

\begin{tabular}{clccccc}
\hline \multirow{2}{*}{ No. } & \multicolumn{1}{c}{ Aspek } & \multicolumn{4}{c}{ Skor Siklus } \\
\cline { 3 - 6 } & & Pre & I & II & III \\
\hline 1. & Membangun/merumuskan masalah & 61 & 65 & 74 & 84 \\
2. & Menyusun strategi pemecahan masalah & 59 & 70 & 76 & 82 \\
3. & Mengusulkan hipotesis pemecahan masalah & 58 & 68 & 78 & 80 \\
4. & Menjelaskan kelemahan dan kelebihan cara pemecahan & 62 & 68 & 73 & 85 \\
\hline & masalah & 60 & 68 & 75 & 83 \\
\hline
\end{tabular}

Tabel 2 menunjukkan adanya tren meningkatnya nilai rerata problem-solving skills mahasiswa pada matakuliah ekologi sebanyak 23 point dari Pra-Siklus ke Siklus III. Pada siklus I dan Siklus II rerata problem-solving skills mahasiswa masih tergolong dalam kategori cukup (namun ada peningkatan nilai sebesar 8 poin). Pada Siklus II dan Siklus III rerata problem-solving skills mahasiswa masih tergolong dalam kategori baik. Nilai rerata problem solving skills pada siklus III sudah hampir mendekati kategori sangat baik (kurang 2 poin). Berdasarkan hal tersebut dapat dikatakan bahwa sudah termasuk kategori sangat baik. Temuan tersebut menunjukkan bahwa model pembelajaran penerapan Blended-PjBL pada matakuliah ekologi cenderung mendorong peningkatan problem-solving skills mahasiswa. 
Problem-solving skills dapat meningkat dan berkembang melalui Blended-PJBl. Hal ini dapat dijelaskan melalui rangkaian/tahapan pembelajaran yang dilaksanakan. Kegiatan pembelajaran dimulai dengan pertanyaan esensial yang dilaksanakan secara tatap muka. Pertanyaan-pertanyaan ini dapat berasal dari dosen maupun dari mahasiswa atau kolaborasi antara keduanya. Pertanyaan penting ini akan menjadi acuan pembelajaran. Menurut Indarti (2016) pertanyaan dan masalah yang dimunculkan sangat penting menuntun mahasiswa ke konsep inti dari subjek. Hal ini memberikan kemungkinan untuk kolaborasi antar disiplin ilmu atau berbagai pengalaman yang telah terkontruksi di dalam pikiran mereka.

Kegiatan kedua berupa mendesain rencana proyek proposal penelitian ekologi hewan tanah. Kegiatan ini melatih mahasiswa untuk menentukan tujuan (menciptakan produk akhir. Menurut Mettas dan Constantinou (2008) tahapan ini merupakan salah satu tahapan yang mendorong mahasiswa untuk memiliki problem-solving. Hal ini karena pada tahap ini mereka akan "mengkaji" topik yang menurut mereka sesuai, merancang produk mereka, dan membuat rencana untuk mengelola proyek. Langlah ini menjadi penentu sebelum mereka memulai proyek, menyelesaikan masalah yang telah ada dan masalah yang muncul berikutnya, dan menyelesaikan produk mereka.

Kegiatan ketiga adalah menentukan jadwal yang dilaksanakan secara tatap muka. Kegiatan membutuhkan keseriusan dan kesepahaman antar anggota/kelompok, oleh karena itu perlu dilakukan secara tatap muka. Menurut Mindtools (2016) kegiatan ini mendorong penguatan problem-solving karena mahasiswa memerlukan beberapa jenis input untuk membuat jadwal proyek, yaitu (1) Kalender pribadi: untuk memahami hari kerja, shift, dan ketersediaan sumber daya sangat penting untuk menyelesaikan jadwal proyek. (2) Deskripsi ruang lingkup proyek: mahasiswa dapat menentukan tanggal mulai dan berakhir, asumsi utama di balik rencana, dan batasan. Mahasiswa juga dapat menuliskan harapan dan target yang ditetapkan dosen. (3) Risiko proyek: mahasiswa perlu memahami ini untuk memastikan ada cukup waktu ekstra untuk menangani risiko yang diidentifikasi - dan dengan risiko yang tidak teridentifikasi. (4) Daftar kegiatan dan persyaratan sumber daya: Amatlah penting untuk menentukan apakah ada kendala lain yang perlu dipertimbangkan ketika mengembangkan jadwal. Memahami kemampuan dan pengalaman sumber daya yang dimiliki-serta hari libur akan memengaruhi jadwal.

Kegiatan keempat adalah memantau mahasiswa dan progres proyek yang dikerjakan yang dilaksanakan secara tatap muka dan daring. Kegiatan untuk memastikan mahasiswa mengerjakan sesuai dengan rencana, memastikan keterlibatan semua anggota, dan meminimalisasi kendala atau bahkan kegagalan yang mungkin mereka hadapi. Menurut Jusoff, Rahman, Daud, dan Ghani (2010) monitoring juga mendorong problem-solving karena kegiatan ini membantu mahasiswa untuk mendapatkan tanggapan dari dosen dan merangsang mereka bagaimana mempertanggungjawabkan perkembangan proyek. Selain itu, mahasiswa yang terlibat dalam membuat tugas proyek atau mengisi daftar periksa proyek mendapatkan pengalaman berharga dalam menetapkan tujuan dan standar keunggulan mereka sendiri.

Sementara itu kegiatan kelima adalah menilai hasil capaian/produk dilaksanakan secara tatap muka dan daring). Sedangkan kegiatan keenam adalah mengevaluasi pengalaman mahasiswa yang dilaksanakan secara daring. Menurut Tai dan Yuen (2007) PjBL menggunakan masalah dan tugas dunia nyata sebagai tujuan inisiatif dalam membangun 
pengetahuan dan meningkatkan pengalaman belajar. PjBL memberikan mahasiswa proyek yang kompleks dan terbuka dan tugas yang membutuhkan integrasi pengetahuan dan keterampilan dalam pemecahan masalah mereka. Sedangkan menurut Shariff, Johan, dan Jamil (2013) pemberian tugas proyek kelompok kepada mahasiswa akan menanamkan dan mengembangkan keterampilan lunak siswa seperti kepemimpinan, komunikasi, kerja tim, dan Problem-solving skill.

Problem-solving skills seseorang dapat terstimulasi oleh kegiatan pembelajaran aktif, yang pada akhirnya mereka terampil menyelesaikan permasalahan dalam kehidupan sehariharinya (Carni, Maknun, \& Siahaan, 2017; Safitri, 2017). Problem-solving skills mahasiswa secara otomatis menyentuh persoalan penalaran untuk membangun pola berpikir kritisnya sejalan dengan tahapan pembelajaran yang dilakukan (Mahroji \& Rufi'i, 2015). Blended$\mathrm{PjBL}$ secara nyata akan mendorong pengembangan problem-solving skills mahasiswa karena memberikan kemudahan untuk mengaplikasikan pengetahuan yang telah dipelajari siswa di kehidupan nyata, dapat melatih dan membiasakan mahasiswa untuk menghadapi dan memecahkan masalah secara terampil (Syahidatulfalah, 2017).

Secara khusus menurut Thomas (2000) Faculty of the Illinois Mathematics and Science Academy and the Chicago Academy of Science telah berkolaborasi dalam studi yang meneliti dampak model PjBL atas prestasi akademik siswa dan problem solving skills. Dalam satu semester, peserta didik disajikan dengan dua masalah "tidak terstruktur" bersama dengan data mentah yang relevan dengan masalah tersebut. Sebagai contoh, informasi diberikan tentang jumlah orang yang meninggal karena penyakit dengan gejala mirip flu di rumah sakit di Illinois. Peserta didik diberi tugas khusus untuk (a) menentukan apakah ada masalah, (b) membuat pernyataan masalah yang tepat, (c) mengidentifikasi informasi yang diperlukan untuk memahami masalah, (d) mengidentifikasi sumber daya yang akan digunakan untuk mengumpulkan informasi, (e) menghasilkan solusi yang mungkin, (f) menganalisis solusi menggunakan analisis manfaat / biaya dan diagram efek riak, dan (g) menulis pernyataan kebijakan yang mendukung solusi yang disukai. Peserta didik bekerja secara mandiri untuk mendefinisikan dan mencari solusi untuk masalah yang diajukan kepada mereka, menyelidiki petunjuk, meminta informasi tambahan, menganalisis data, dan lain-ain. Hasil dari penelitian ini berfokus pada kinerja pada tes penyelesaian masalah yang diberikan baik sebagai pretest maupun posttest. Respons mereka dinilai menggunakan daftar periksa "enam" langkah atau enam kategori. Hasil menunjukkan adanya peningkatan yang signifikan antara pretest dan posttest untuk kelompok eksperimen terkait dengan problem solving skills.

Hal ini sejalan dengan Sart (2014), bahwa melalui PjBL dengan konteks memecahkan masalah yang berbeda dimungkinkan untuk mengembangkan ide-ide kreatif sambil meningkatkan keterampilan berpikir lainnya. Sart menganalisis bahwa sebagian besar (86\%) mahasiswa sepakat bahwa pembelajaran PjBL dengan memecahkan masalah yang berbeda jauh lebih baik daripada pembelajaran tradisional. Sebagian besar (81\%) mahasiswa menunjukkan bahwa kesadaran mereka meningkat secara nyata $(68 \%)$ dalam pembelajaran PjBL dibandingkan pembelajaran tradisional. Akibatnya, kasus-kasus dan tantangan seharihari, termasuk sosial, ekonomi, budaya, dan lingkungan diselesaikan dalam desain proyek Dalam PjBL, dengan memecahkan masalah yang berbeda dimungkinkan untuk mengembangkan ide-ide kreatif sambil meningkatkan keterampilan yang sangat berkembang. 
Penelitian oleh Yaniawati (2013) menunjukkan bahwa dalam kelompok blended learning, dalam menyelesaikan masalah yang memerlukan analisis, siswa relatif memiliki konsep yang lebih luas dibandingkan dengan siswa di kelompok lain. Berbeda dari kelompok lain (e-learning penuh dan konvensional), mayoritas siswa tidak menjawab sepenuhnya (mengosongkan jawaban). Berdasarkan fakta-fakta ini, dapat dilihat bahwa blended learning dapat memperluas konsep mahasiswa dan mengembangkan cara berpikir kreatif.

PjBL berguna untuk membuat mahasiswa aktif dalam proses pembelajaran dan untuk mendorong pencapaian keterampilan yang diperlukan untuk profesi dan kehidupan mereka kelak. Data menunjukkan bahwa model tersebut berhasil meningkatkan pengalaman belajar mahasiswa dan meningkatkan problem solving (Shinde, 2014). PjBL mengembangkan keterampilan mahasiswa dalam bidang problem solving, pemikiran kritis, visualisasi, pengambilan keputusan, dan penalaran, serta dalam komunikasi tertulis dan lisan. Mahasiswa yang terlibat dalam proses pembelajaran $\mathrm{PjBL}$ bertanggung jawab atas pembelajaran mereka sendiri dan menjadi pembelajar seumur hidup. Temuan penelitian ini juga sejalan pula dengan beberapa penelitian sebelumnya bahwa Blended-PjBL mendorong pengembangan kemampuan berpikir (Husamah, 2015; Putri \& Hendawati, 2014; Widyasari et al., 2018).

\section{Hasil Belajar}

Gambar 1 menyajikan tren rerata hasil belajar mahasiswa pada mata kuliah ekologi. Indikator yang dijadikan alat ukur hasil belajar siswa adalah hasil tes ulangan harian, proses pengerjaan proyek.

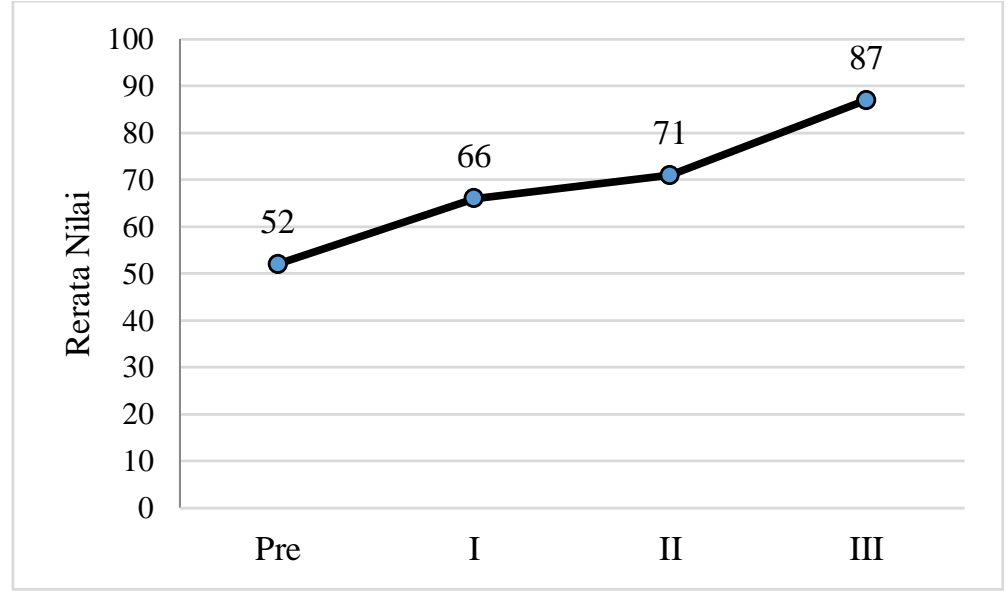

Gambar 1. Tren rerata hasil belajar mahasiswa pada matakuliah ekologi

Data yang ditunjukkan pada Gambar 1 adalah rerata hasil belajar mahasiswa di siklus I masih rendah (masih tergolong nilai $\mathrm{C} / \mathrm{C}+$ ) meskipun telah meningkat 14 poin. Kondisi ini masih dapat dimaklumi mengingat bahwa para mahasiswa masih baru mengenal Blended$\mathrm{PjBL}$, mereka masih menyesuaikan dengan kondisi pembelajaran. Namun demikian aktivitas mereka dalam pembelajaran terus meningkat. Di siklus II, hasil belajar mahasiswa telah meningkat menjadi 71 (tergolong nilai B). Keaktifan dan keterlibatan mahasiswa terus meningkat, mereka mulai terbiasa dengan pembelajaran Blended-PjBL. Keberagaman aktivitas dan tugas yang diberikan membuat para mahasiswa semakin aktif sehingga mereka memiliki keberagaman pengalaman belajar. Pada Siklus III, nilai rerata mahasiswa sudah 
mencapai 87 (tergolong nilai A). Dengan demikian, dari pre-siklus hingga siklus III terdapat peningkatan sebesar 35 poin. Tren peningkatan nilai rerata hasil belajar mahasiswa patut diduga karena Blended-PjBL mendorong peningkatan aktivitas belajar mahasiswa. Aktivitas mereka semakin luas dan beragam karena memadukan tatap muka langsung dan daring, kelas lebih kondusif sebab setiap orang dapat terlibat tanpa terbatasi waktu dan ruang. Sumber pengayaan pengetahuan juga semakin beragam karena mereka dapat menggunakan fasilitas daring.

Menurut Kingston (2018) berita baiknya adalah penelitian menunjukkan bahwa PjBL dapat mendorong siswa utuk belajar dan mungkin lebih efektif daripada pengajaran tradisional dalam studi sosial, sains (termasuk biologi), matematika, dan literasi. Hasil 20 penelitian yang ditinjau secara singkat menunjukkan bahwa PjBL dapat mempromosikan pembelajaran siswa dalam studi sosial dan sains; dan, pada tingkat yang lebih terbatas, pada pembelajaran matematika dan literasi. Terus munculnya temuan penelitian untuk mendukung PjBL sebagai metode pembelajaran yang valid, termasuk mereka yang membutuhkan perhatian khusus. Namun, penelitian lebih lanjut diperlukan untuk menunjukkan hubungan sebab akibat antara PjBL dan hasil belajar siswa/mahasiswa. Seiring dengan penelitian yang terus dibangun, praktisi yang tertarik menggunakan $\mathrm{PjBL}$ dapat merujuk pada bukti studi PjBL dalam meningkatkan hasil belajar. Sejalan dengan itu hasil penelitian Johnson (2016) menunjukkan adanya peningkatan signifikan prestasi akademik (hasil belajar) mahasiswa melalui penggunaan PjBL dalam konteks kelas psikologi. Karena penelitian hanya lebih dari satu setengah bulan, penelitian di masa depan dapat melibatkan periode waktu yang lebih lama untuk mendapatkan data yang lebih dapat diandalkan tentang efek PjBL yang meningkatkan prestasi akademik. Hasil penelitian Baş (2011) juga menunjukkan bahwa pembelajaran PjBL lebih efektif dalam pengembangan positif tingkat prestasi akademik siswa. Pada akhir penelitian, terungkap bahwa peserta yang dididik dalam kelas PjBL lebih sukses dan memiliki tingkat sikap yang lebih tinggi terhadap pelajaran daripada peserta didik yang dididik dalam pembelajaran yang hanya berdasarkan buku teks.

\section{SIMPULAN DAN SARAN}

\section{Simpulan}

Penerapan Blended-PjBL mampu meningkatkan problem-solving skills hingga level baik dan hasil belajar hingga level sangat baik pada matakuliah ekologi. Implikasi implementasi Blended-PjBL, yaitu 1) model ini memadukan keunggulan PjBL dengan kelebihan aspek daring/online, diawali dengan memulai dengan pertanyaan esensial atau start with the essential question (dilaksanakan secara tatap muka) hingga mengevaluasi pengalaman mahasiswa atau evaluate the experience (dilaksanakan secara daring); (2) penerapan Blended-PjBL dapat dilaksanakan secara fleksibel, menyesuaikan pada kondisi kelas/lingkungan, sarana-prasarana, karakteristik mahasiswa, dan karakteristik materi/matakuliah. 


\section{Saran}

Oleh sebab itu dapat diberikan saran bahwa Blended-PjBL bersifat fleksibel dan perlu untuk terus dikembangkan sesuai dengan karakteristik materi dan fasilitas. Sangat disarankan penerapan Blended-PjBL dalam berbagai materi dan tingkatan semester, dengan orientasi yang mengarah pada pengembangan kemampuan abad ke-21.

\section{DAFTAR PUSTAKA}

Allchin, D. (2013). Problem- and case-based learning in science: An introduction to distinctions, values, and outcomes. CBE Life Sciences Education, 12(3), 364-372. https://doi.org/10.1187/cbe.12-11-0190

Arikunto, S. (2001). Prosedur penelitian (Suatu pendekatan praktek). Jakarta: PT. Rineka Cipta.

Asyafah, A. (2014). Research based instruction in the teaching of islamic education. SpringerPlus, 3(1), 1-5. https://doi.org/10.1186/2193-1801-3-755

Baş, G. (2011). Investigating the effects of project-based learning on students' academic achievement and attitudes towards English lesson. TOJNED: The Online Journal of New Horizons In Education, 1(4), 1-15. Retrieved from https://www.tojned.net/journals/tojned/articles/v01i04/v01i04-01.pdf

Bouwma-Gearhart, J. L., Ivanovitch, J. D., Aster, E. M., \& Bouwma, A. M. (2018). Exploring postsecondary biology educators' planning for teaching to advance meaningful education improvement initiatives. CBE Life Sciences Education, 17(3), 1-12. https://doi.org/10.1187/cbe.17-06-0101

Bustami, Y., Syafruddin, D., \& Afriani, R. (2018). The implementation of contextual learning to enhance biology students' critical thinking skills. Jurnal Pendidikan IPA Indonesia, 7(4), 451-457. https://doi.org/10.15294/jpii.v7i4.11721

Caraka, P., \& Ika, M. (2016). Strategi LPTK Dalam pengembangan kompetensi pedagogik calon guru. Jurnal Pendidikan (Teori Dan Praktik), 1(2), 96-106. https://doi.org/10.26740/jp.v1n2.p98-106

Carni, C., Maknun, J., \& Siahaan, P. (2017). An implementation of ICARE approach (introduction, connection, application, reflection, extension) to improve the creative thinking skills. In IOP Conf. Series: Journal of Physics: Conf. Series (Vol. 812, pp. 1-5). https://doi.org/10.1088/1742-6596/812/1/012022

Chaudhry, N. G., \& Rasool, G. (2012). A case study on improving problem solving skills of undergraduate computer science students. World Applied Sciences Journal, 20(1), 34-39. https://doi.org/10.5829/idosi.wasj.2012.20.01.1778

Darling-Hammond, L., Flook, L., Cook-Harvey, C., Barron, B., \& Osher, D. (2019). Implications for educational practice of the science of learning and development. Applied Developmental Science, O(0), 1-44. https://doi.org/10.1080/10888691.2018.1537791

Ebiere Dorgu, T. (2016). Different teaching methods: A Panacea for effective curriculum implementation in the classroom. International Journal of Secondary Education, 3(6), 77-87. https://doi.org/10.11648/j.ijsedu.s.2015030601.13

Faisal, \& Martin, S. N. (2019). Science education in Indonesia: past, present, and future. AsiaPacific Science Education, 5(1). https://doi.org/10.1186/s41029-019-0032-0

Filho, W. L., Raath, S., Lazzarini, B., Vargas, V. R., de Souza, L., Anholon, R., ... Orlovic, V. L. (2018). The role of transformation in learning and education for sustainability. Journal of Cleaner Production, 199, 286-295. 
https://doi.org/10.1016/j.jclepro.2018.07.017

Fry, H., Ketteridge, S., \& Marshall, S. (Eds.). (2009). A handbook for teaching and learning in higher education: Enhancing academic practice. Routledge Taylor \& Francis Group (3rd ed.). New York and London: Routledge. https://doi.org/10.1080/17439884.2010.481558

Hakim, A. (2015). Contribution of competence teacher (Pedagogical, personality, professional competence and social) on the performance of learning. The International Journal of Engineering And Science, 4(2), 1-12. Retrieved from www.theijes.com

Husain, I., Katili, A. S., \& Nusantari, E. (2019). Pengembangan buku ajar ekologi dengan memanfaatkan hasil analisis potensi ekosistem mangrove sebagai penyerap karbon. Jambura Edu Biosfer Journal, 1(1), 23-31. https://doi.org/10.34312/jebj.v1i1.2043

Husamah, H. (2015). Blended project based learning: Metacognitive awareness of biology education new students. Journal of Education and Learning, 9(4), 274-281. https://doi.org/10.11591/edulearn.v9.i4.2121

Husamah, H., \& Pantiwati, Y. (2014). Cooperative learning STAD-PjB: Motivation, thinking skills, and learning outcomes of biology department students. International Journal of Education Learning and Development, 2(1), 77-94.

Indarti, I. (2016). Implementing project-based learning (PBL) in final collection to improve the quality of fashion design student. Innovation of Vocational Technology Education, 12(1), 22-30. https://doi.org/10.17509/invotec.v12i1.4500

Jeronen, E., Palmberg, I., \& Yli-Panula, E. (2016). Teaching methods in biology education and sustainability education including outdoor education for promoting sustainabilityA literature review. Education Sciences, 7(1), 1-19. https://doi.org/10.3390/educsci7010001

Johnson, A. (2016). The effect of project based learning on the academic achievement of atrisk advanced placement students. Graduate Programs in Education Goucher College.

Jusoff, K., Rahman, B. H. A., Daud, K. A. M., \& Ghani, N. A. A. (2010). Motivating students using project based learning (PjBL) via e-SOLMS technology. World Applied Sciences Journal, 8(9), 1086-1092.

Kemmis, S., McTaggart, R., \& Nixon, R. (2014). The action reseacrh planner: Doing critical participatory action research. Singapore: Springer. Retrieved from http://www.springer.com/978-981-4560-66-5

Khatoon, Z., Alam, M. T., Bukhari, M. A., \& Mushtaq, M. (2014). In-service teachers' perception about their competencies in delivery of biology lessons, 4(7), 820-834. Retrieved from www.aessweb.com/pdf-files/ijass-2014

Khoiriyah, A. J., \& Husamah, H. (2018). Problem-based learning: Creative thinking skills, problem-solving skills, and learning outcome of seventh grade students. JPBI (Jurnal Pendidikan Biologi Indonesia), 4(2), 151-160. https://doi.org/10.22219/jpbi.v4i2.5804

Kingston, S. (2018). Project based learning \& student achievement: What does the research tell us? PBL Evidence Matters, 1(1), 1-11.

Kristianti, T. P., Ramli, M., \& Ariyanto, J. (2018). Improving the argumentative skills of high school students through teacher's questioning techniques and argumentative assessment. Journal of Physics: Conference Series, 1013(1). https://doi.org/10.1088/17426596/1013/1/012012

Le, H., Janssen, J., \& Wubbels, T. (2018). Collaborative learning practices: teacher and student perceived obstacles to effective student collaboration. Cambridge Journal of 
Education. https://doi.org/10.1080/0305764X.2016.1259389

Mahanal, S., \& Zubaidah, S. (2017). Model pembelajaran Ricosre yang berpotensi memberdayakan keterampilan berpikir kreatif. Jurnal Pendidikan: Teori, Penelitian, Dan Pengembangan, 2(5), 676-685.

Mahanal, S., Zubaidah, S., Bahri, A., \& Dinnurriya, M. S. (2016). Improving students' critical thinking skills through Remap NHT in biology classroom. Asia-Pacific Forum on Science Learning and Teaching, 17(2). Retrieved from https://www.eduhk.hk/apfslt/v17_issue2/zubaidah/page2.htm

Mahroji, M., \& Rufi'i, R. (2015). Pengembangan model active learning ICARE system pada pembelajaran matematika untuk siswa kelas VII. Jurnal Teknologi Pembelajaran Devosi, 5(2), 195-203.

Martiningsih, I., Lisdiana, L., \& Susilowati, S. M. E. (2018). Development of module based on scientific contextual additives material to increase learning outcomes and science process skills in junior high school. Journal of Innovative Science Education, 7(1), 372381. https://doi.org/10.15294/jise.v0i0.27790

Mettas, A. C., \& Constantinou, C. C. (2008). The technology fair: A project-based learning approach for enhancing problem solving skills and interest in design and technology education. International Journal of Technology and Design Education, 18(1), 79-100. https://doi.org/10.1007/s10798-006-9011-3

Mindtools. (2016). Project schedule development - Project management from MindTools.com. $\quad$ Retrieved October 1, 2019, from https://www.mindtools.com/pages/article/newPPM_71.htm

Montrieux, H., Vanderlinde, R., Schellens, T., \& De Marez, L. (2015). Teaching and learning with mobile technology: A qualitative explorative study about the introduction of tablet devices in secondary education. PLOS ONE, 10(12), 1-17. https://doi.org/10.1371/journal.pone.0144008

Mwanda, G., Odundo, P., \& Midigo, R. (2017). Towards adoption of constructivist instructional approach in learning biology in secondary school students in Kenya: Addressing learner attitude. International Journal of Secondary Education, 5(1), 1. https://doi.org/10.11648/j.ijsedu.20170501.11

Nepal, K. P., \& Jenkins, G. (2011). Blending project-based learning and traditional lecturetutorial-based teaching approaches in engineering design courses. In Australasian Association for Engineering Education (AAEE) Conference Proceedings (pp. 338-343). Fremantle, Western Australia: AAEE. Retrieved from https://researchrepository.griffith.edu.au/handle/10072/46601

Ngang, T. K., Hashim, N. H., \& Yunus, H. M. (2015). Novice teacher perceptions of the soft skills needed in today's workplace. In Procedia - Social and Behavioral Sciences (Vol. 177, pp. 284-288). Elsevier B.V. https://doi.org/10.1016/j.sbspro.2015.02.338

Nurhamidah, D., Masykuri, M., \& Dwiastuti, S. (2018). Profile of senior high school students' creative thinking skills on biology material in low, medium, and high academic perspective. Journal of Physics: Conference Series, 1006(1). https://doi.org/10.1088/1742-6596/1006/1/012035

Nursal, N., \& Fauziah, Y. (2013). Efektifitas penerapan lesson study pada pembelajaran ekologi tumbuhan di program studi pendidikan biologi FKIP Universitas Riau. In Prosiding Semirata FMIPA Universitas Lampung (pp. 199-204). Bandar Lampung: FMIPA Universitas Lampung. Retrieved from https://jurnal.fmipa.unila.ac.id/index.php/semirata/article/viewFile/608/428 
Ogunyinka, E. K., Okeke, T. I., \& Adedoyin, R. C. (2015). Teacher education and development in Nigeria: An analysis of reforms, challenges and prospects. Education Journal, 4(3), 111. https://doi.org/10.11648/j.edu.20150403.14

Owens, M. T., \& Tanner, K. D. (2017). Teaching as brain changing: Exploring connections between neuroscience and innovative teaching. CBE Life Sciences Education, 16(2), 1-9. https://doi.org/10.1187/cbe.17-01-0005

Pachauri, D., \& Yadav, A. (2013). Importance of soft skills in teacher education programme. IJERT International Journal of Educational Research, 41(5), 22-25.

Papathanasiou, I. V., Kleisiaris, C. F., Fradelos, E. C., Kakou, K., \& Kourkouta, L. (2014). Critical thinking: The development of an essential Skill for nursing students. Acta Informatica Medica, 22(4), 283-286. https://doi.org/10.5455/aim.2014.22.283-286

Putri, S. U., \& Hendawati, Y. (2014a). Blended project based learning: Strategy for improving critical thinking of pre-service teachers in science education. In Proceeding of the 1st UR International Conference on Educational Sciences (pp. 978-979). Retrieved from https://ejournal.unri.ac.id/index.php/ICES/article/view/4745

Putri, S. U., \& Hendawati, Y. (2014b). Blended project based learning: Strategy for improving critical thinking of pre-service teachers in science education. In Proceeding of the 1st UR International Conference on Educational Sciences (pp. 978-979).

Ramlawati, Mun'Im, A., \& Yunus, S. R. (2018). Improving pedagogical competences of prospective science teachers to develop learning materials through Jigsaw cooperative model. In Journal of Physics: Conference Series (Vol. 1028, pp. 1-6). https://doi.org/10.1088/1742-6596/1028/1/012209

Rasmani, U. E. E., Widodo, J., \& Wibowo, M. E. (2017). A model for developing soft skill training management oriented toward service quality for shs couselors. The Journal of Educational Development, 5(1), 39-49. https://doi.org/10.15294/jed.v5i1.12993

Rhodes, T. (2009). Assessing outcomes and improving achievement: Tips and tools for using the rubrics. Washington, DC: Association of American Colleges and Universities.

Rohaeti, E. E. (2014). Developing a balanced hard skill and soft skill of students' math through the character-oriented scientific approach. In International Seminar on Innovation in Mathematics and Mathematics Education 1st ISIM-MED (pp. 369-376). Yogyakarta: Department of Mathematics Education,Yogyakarta State University. Retrieved from https://eprints.uny.ac.id/24336/1/E-43.pdf

Rohman, A. (2013). Peran LPTK dalam mempersiapkan guru yang kompeten. Jurnal AtTaqaddum, 5(2), 282-301. https://doi.org/10.21580/at.v5i2.700

Safitri, T. A. (2017). Penerapan model pembelajaran problem based instruction (PBI) berbasis ICARE untuk meningkatkan kemampuan pemecahan masalah siswa pada materi pencemarn lingkungan. UIN Sunan Gunung Djati Bandung.

Sart, G. (2014). The effects of the development of metacognition on project-based learning. In Procedia - Social and Behavioral Sciences (Vol. 152, pp. 131-136). Elsevier B.V. https://doi.org/10.1016/j.sbspro.2014.09.169

Schinske, J., \& Tanner, K. (2014). Teaching more by grading less (or differently ). CBE-Life Sciences Education, 13, 159-166. https://doi.org/10.1187/cbe.14-03-0054

Serdyukov, P. (2017). Innovation in education: What works, what doesn't, and what to do about it? Journal of Research in Innovative Teaching \& Learning, 10(1), 4-33. https://doi.org/10.1108/jrit-10-2016-0007

Shariff, S. M., Johan, Z. J., \& Jamil, N. A. (2013). Assessment of project management skills 
and learning outcomes in students' projects. In Procedia - Social and Behavioral $\begin{array}{llllll}\text { Sciences } & \text { (Vol. } & \text { 90, } & \text { 745-754). } & \text { Elsevier } & \text { B.V. }\end{array}$ https://doi.org/10.1016/j.sbspro.2013.07.148

Shieh, R. S., \& Chang, W. (2014). Fostering student's creative and problem-solving skills through a hands-on activity. Journal of Baltic Science Education, 13(5), 650-661. Retrieved from http://www.scientiasocialis.lt/jbse/files/pdf/vol13/650661.Shieh_JBSE_Vol.13_No.5.pdf

Shinde, V. (2014). Design of course level project based learning models for an Indian Engineering Institute: An assessment of students 'learning experiences and learning outcomes. Aalborg University Press, Denmark. Retrieved from http://citeseerx.ist.psu.edu/viewdoc/download?doi=10.1.1.1000.3249\&rep=rep1\&type=p df

Sukerti, N. W. (2016). Optimalisasi peran LPTK dalam upaya meningkatkan kualitas lulusan bidang tata boga di era MEA. In Seminar Nasional Vokasi dan Teknologi (SEMNASVOKTEK) (pp. 119-126). Denpasar-Bali: Universitas Pendidikan Ganesha. Retrieved from http://eproceeding.undiksha.ac.id/index.php/semnasvoktek/article/view/61

Suryawati, E., Linggasari, M. N., \& Arnentis, A. (2017). Technological pedagogical and content knowledge of biology prospective teachers. Biosaintifika: Journal of Biology \& Biology Education, 9(3), 498. https://doi.org/10.15294/biosaintifika.v9i3.11270

Syahidatulfalah, S. (2017). Penerapan model pembelajaran problem solving berbasis ICARE untuk meningkatkan kemampuan berpikir kreatif peserta didik pada materi pencemaran lingkungan (Penelitian terhadap peserta didik kelas VII SMP N 1 Gunungguruh). Sukabumi Tahun.

Tai, G. X. L., \& Yuen, M. C. (2007). Authentic assessment strategies in problem based learning. In ASCILITE 2007 - The Australasian Society for Computers in Learning in Tertiary Education (pp. 983-993).

Tang, K. N. (2018). The importance of soft skills acquisition by teachers in higher education institutions. Kasetsart Journal of Social Sciences, 2-7. https://doi.org/10.1016/j.kjss.2018.01.002

Tanner, K. D. (2017). Structure matters: Twenty-one teaching strategies to promote student engagement and cultivate classroom equity. CBE-Life Sciences Education, 12(3), 322331. https://doi.org/10.1187/cbe.13-06-0115

Thomas, J. W. (2000). A Review of research on project-based learning. San Rafael, California 94903.

White, B., Stains, M., Escriu-Sune, M., Medaglia, E., Rostamnjad, L., Chinn, C., \& Sevian, H. (2011). A novel instrument for assessing students' critical thinking abilities. Journal of College Science Teaching, 40(5), 102-107. Retrieved from https://pdfs.semanticscholar.org/5465/c511a150bce0332152a459aebd737f163823.pdf

Widyasari, F., Indriyanti, N. Y., \& Mulyani, S. (2018). Pengaruh pembelajaran kimia dengan model PjBL dan PBL berdasarkan representasi tetrahedral kimia ditinjau dari kreativitas siswa. JKPK (Jurnal Kimia Dan Pendidikan Kimia), 3(2), 93-102. https://doi.org/10.20961/jkpk.v3i2.16638

Yaniawati, R. P. (2013). E-learning to improve higher order thinking skills (HOTS) of students. Journal of Education and Learning (EduLearn), 7(2), 109. https://doi.org/10.11591/edulearn.v7i2.225 


\section{UCAPAN TERIMA KASIH}

Tim peneliti menyampaikan terima kasih kepada Direktorat Penelitian dan Pengabdian Masyarakat Universitas Muhammadiyah Malang (DPPM-UMM) yang telah mendanai kegiatan penelitian in melalui skema Penelitian Dasar Keilmuan (PDK) tahun 2019.

\section{PROFIL SINGKAT}

Erna Yayuk, S.Pd., M.Pd., lahir pada tanggal 24 Agustus 1982. Saat ini Ia merupakan dosen tetap di prodi PGSD FKIP Universitas Muhammadiyah Malang dengan spesialisasi bidang matematika. S1 diselesaikannya di prodi pendidikan matematika Universitas Muhammadiyah Malang dan S2 di Universitas Negeri Malang. Saat ini Ia juga sedang menempuh S3 di pascasarjana Universitas Negeri Malang.

Husamah, S.Pd.,M.Pd., dilahirkan di Sumenep, 18 Oktober 1985. Pendidikan S1 ditamatkan di Prodi Pendidikan Biologi FKIP Universitas Muhammadiyah Malang. S2 ditamatkannya di Pendidikan Biologi Pascasarjana Universitas Negeri Malang. Saat ini Ia menjadi dosen tetap di Prodi Pendidikan Biologi Universitas Muhammadiyah Malang dan banyak meneliti tema-tema pendidikan maupun pengembangan kemampuan berpikir. 